\title{
Detection of Human Papilloma Virus (HPV) in oral mucosa of women with cervical lesions and their relation to oral sex practices
}

\author{
Luis O Sánchez-Vargas', Cecilia Díaz-Hernández², Alejandro Martinez-Martinez ${ }^{1 *}$
}

\begin{abstract}
Background: Previous studies have either investigated the relationship of HPV with oral cancer or the prevalence of HPV on the oral cavity. The purpose of this investigation was to study the prevalence of HPV in oral cavity of women with oral sex practices and cervical lesions.

Methods: Forty six (46) non-smokers and non-alcoholic patients attended the "Clínica de Displasias" of "Ciudad Juarez" were sampled. This population had a CIN diagnosis sometime between the previous six months. On previous consent they filled out a questionnaire related to their oral sex practices. Afterwards one swab from cheeks and another from palate/gum were taken; PCR was used to determine generic HPV, HPV16 and HPV18.

Results: Seventy two percent (72\%) of the patients stated to have oral sex practices regularly which all of them were positive to HPV either in oral mucus, palate/gum or both. The total of the given results showed that $35 \%$ had HPV16; among those distributed in 26\% with regular oral sex practices and $9 \%$ stated as never practiced oral sex. An association was found between oral HPV16 positivity and progression to cervical CIN advanced lesions. On the other hand HPV18 was not detected. The frequency of HPV16 was higher in buccal mucosa (23\%) versus palate/ gum (16\%).
\end{abstract}

Conclusions: This study suggests that buccal HPV16 infection is associated with CIN progression.

\section{Background}

Human papillomaviruses (HPVs) are a family of small $(55 \mathrm{~nm})$ icosahedral, non-enveloped virus with a circular double-stranded DNA genome of 7-8 kbp and with a special affinity for epithelial cells [1,2]. Over 200 genotypes of papillomaviruses infect the skin and mucosal surfaces [2]. The most common oncogenic HPV are associated with leukoplakia and squamous carcinoma. While the majority of the HPV types have affinity to grow on skin, oral lesions, genitals, anal and larynx [1]. Some HPV types are considered as high risk; most notably $16,18,31,33,35,39,45,52$, and 58 and have been shown to be a necessary cause for Cervical Cancer development [3]. Cervical cancer is a major public health problem around the world; in some developing countries it is the most frequent female cancer, as well

\footnotetext{
* Correspondence: alejandro.martinez@uacj.mx

${ }^{1}$ Instituto de Ciencias Biomédicas, Universidad Autónoma de Ciudad Juárez, Ciudad Juárez, Chihuahua, México

Full list of author information is available at the end of the article
}

as the main cause of cancer related death among women $[4,5]$.

The potentially oncogenic HPVs has been associated with oral squamous cell carcinoma [6,7]. Some evidence has linked them to orogenital contact with the transmission of papillomavirus from the genital zone to the oral cavity [8]. It is suggested that oral HPV infection frequency is different from cervical infection and associated with age [9]. Other studies have detected the presence of HPV in the epithelium of the oropharynx in women with genital HPV by using a cytological examination and the Papanicolaou technique [10]. These studies alert the possibility of a natural reservoir of HPV at a locus outside of the genital region, which could serve as a reinfection focus [10]. Additionally the HPV is rarely present in the vagina of virgin women even with the use of tampons or digital penetration [11].

Despite the recognition of a HPV-associated oral malignancy, it is unclear to what extent cervical HPV infection is translocated to oral HPV infection. Previous

\section{Ciomed Central}


studies suggested that oral HPV infection analogously to cervical infection is associated with sexual behavior and immunosuppressant $[12,13]$. The majority of the studies of buccal HPVs made in the past have explored the relationship between HPV and the development of oral cancer; these studies detected HPV in DNA extracted from the oral cavity of patients with oral lesions and/or abnormalities [14-18] shown that HPVs that infect the genital area can also infect the oral cavity [19]. In healthy Japanese; HPV in oral cavity was present in $0.6 \%$ of the population [20]. Other studies have proposed that mothers may serve as the source of infant HPV infection which suggested the possibility of a non-sexual transmission of the virus [21]. In the few studies in which oral and anogenital HPV infections were analyzed, oral HPV infection frequency appeared to be lower than anogenital infection [16,17,22,23]. However, oral and cervical HPV prevalence were similar in a small group with high prevalence of oral or anogenital condylomata [16]. These studies were performed in a high risk population therefore the relationship between HPV infection in cervix and oral cavity related to oral sex practices remains unexplored. The aim of this study was to determine the frequency of HPV in the oral cavity of a Mexican women population with histopathological diagnosis of cervical lesions and to describe the viral infection in relation to oral sex practices and habits to share personal objects such as toothbrush.

\section{Results}

This study included 46 voluntary non-smoker and nonalcoholic women that attend to the "Clínica de Displasias del Sector Salud" in the City of Juarez, México. The female subjects attend to this clinic because they presented previous CIN alterations. After they filled out the inform consent and the questionnaire; the patients were instructed by imitation for autosampling the oral cavity. Once in the laboratory and after DNA extraction the human $\beta$-globin gene was amplified as an internal control of human DNA as well as a DNA with quality for PCR. Those cases that failed in the $\beta$-globin gene amplification were excluded rather than those samples tested positive for $\beta$-globin were further used for generic HPV that amplify a wide range of HPV types. After generic HPV positivity the specific PCR for HPV16 and HPV18 were performed. Two regions were sampled in the oral cavity; the first one was the buccal mucosa and the second one was the palate and gum altogether $(\mathrm{P} / \mathrm{G})$. All women studied carried generic HPV either in mucosa or $\mathrm{P} / \mathrm{G}$, this gives a frequency of $100 \%$ for the buccal cavity. However, if the mucosa and $\mathrm{P} / \mathrm{G}$ are considered separately (Table 1) the percentages of HPV infection were as follows: for generic HPV in the buccal mucosa was $86 \%$, and for $\mathrm{P} / \mathrm{G}$ was $88 \%$ and for HPV16 23\% for
Table 1 Frequency of HPV by buccal region and its relation with oral sex practices

\begin{tabular}{|c|c|c|c|c|c|}
\hline \multirow{2}{*}{$\begin{array}{l}\text { Overall }(\mathbf{N}=\mathbf{4 3}) \\
\text { Buccal mucosa }\end{array}$} & \multirow[t]{2}{*}{ Oral sex } & \multicolumn{2}{|c|}{ Generic HPV } & \multicolumn{2}{|c|}{ HPV16 } \\
\hline & & $n$ & $(\%)$ & $n$ & $(\%)$ \\
\hline & No & 11 & 26 & 3 & 7 \\
\hline & Yes & 26 & 60 & 7 & 16 \\
\hline & Total & 37 & 86 & 10 & 23 \\
\hline \multirow[t]{4}{*}{ Palate/gum } & & $n$ & $(\%)$ & $n$ & $(\%)$ \\
\hline & No & 9 & 21 & & 2 \\
\hline & Yes & 29 & 67 & 6 & 14 \\
\hline & Total & 38 & 88 & 7 & 16 \\
\hline
\end{tabular}

mucosa and $16 \%$ for $P / G$. The higher frequency of HPV16 in woman having oral sex would suggest a higher risk, however number are too small to see any significant risk.

Sixty-three percent (63\%) of the studied female subjects were married, $19 \%$ were in common law marriage and $7 \%$ were singles. The mean age was 35 years old ranging between 19 to 63 years old (not shown in tables). Table 2 shows the results of the applied questionnaire. Generic HPV was detected in all cases either in palate-gum, buccal mucosa, or both. However, HPV16 was detected in $35 \%$ of all patients and $73 \%$ of the patients stated to practice oral sex frequently. The association between the presence of HPV16 and the frequently practice of oral sex was not observed. From the total women, 53\% had oral sex mutually (fellatio and cunnilingus, Table 2). This group had the highest frequency of HPV16 (53\%) among those patients stated to practice oral sex. Interestingly the only three women that practice fellatio but did not received cunnilingus (7\%) were generic HPV positive but HPV16 negative.

All women were CIN diagnosed along the previous six months (according to Bethesda classification) because of that; it is clearly evident the association between oral HPV16 positivity and CIN progression 51\% (Mann Whitney $U$ test, $\mathrm{p}=0.023)$, followed by $28 \%$ with inflammatory alterations; and finally $21 \%$ did not present cervical alterations (Table 2). Two women that evolved positively to the treatment at that time of gynecological visit were observed. They had no cervical alterations but were HPV16 positive.

The majority of the patients stated not to use condoms while practicing oral sex, and $60 \%$ of them were buccal HPV16 positive. Apparently the use of condoms during oral sex would prevent infection of the oral mucosa (Table 2).

The biggest group of patients (47\%) declared to have only one sex partner, $23 \%$ had two partners and $2 \%$ had more than two partners (Table 2). 
Table 2 Buccal HPV16 associated to oral sex practices

\begin{tabular}{|c|c|c|c|c|c|c|}
\hline & \multicolumn{2}{|c|}{ Overall $(\mathrm{N}=43)$} & \multicolumn{2}{|c|}{ HPV16 negative $(\mathrm{N}=28)$} & \multicolumn{2}{|c|}{ HPV16 positive $(\mathrm{N}=15)$} \\
\hline & $\mathrm{n}$ & $\%$ & $\mathrm{n}$ & $\%$ & $\mathrm{n}$ & $\%$ \\
\hline \multicolumn{7}{|l|}{ Oral Sex frequency } \\
\hline Never & 12 & 28 & 8 & 29 & 4 & 27 \\
\hline Frequently & 31 & 72 & 20 & 71 & 11 & 73 \\
\hline \multicolumn{7}{|l|}{ Oral Sex type } \\
\hline Do not practice & 1 & 2 & 1 & 4 & 0 & 0 \\
\hline To her partner & 3 & 7 & 3 & 11 & 0 & 0 \\
\hline Both & 23 & 53 & 15 & 54 & 8 & 53 \\
\hline Did not answer & 16 & 37 & 9 & 32 & 7 & 47 \\
\hline \multicolumn{7}{|c|}{ *Histological biopsy results } \\
\hline Without alterations & 9 & 21 & 7 & 25 & 2 & 13 \\
\hline Inflammatory Alterations & 12 & 28 & 9 & 32 & 3 & 20 \\
\hline $\mathrm{CIN}-\mathrm{I} \& \mathrm{CIN}-\mathrm{II}$ & 22 & 51 & 12 & 43 & 10 & 67 \\
\hline \multicolumn{7}{|c|}{ Use of condom while practicing oral sex } \\
\hline Do not practice oral sex & 12 & 28 & 8 & 29 & 4 & 27 \\
\hline Use of Condom & 1 & 2 & 1 & 4 & 0 & 0 \\
\hline Do not use Condom & 25 & 58 & 16 & 57 & 9 & 60 \\
\hline Did not answer & 5 & 12 & 3 & 11 & 2 & 13 \\
\hline \multicolumn{7}{|c|}{ Number of Partners to whom practice oral sex } \\
\hline Do not practice oral sex & 1 & 2 & 1 & 4 & 0 & 0 \\
\hline One & 20 & 47 & 12 & 43 & 8 & 53 \\
\hline Two & 10 & 23 & 7 & 25 & 3 & 20 \\
\hline More than two & 1 & 2 & 1 & 4 & 0 & 0 \\
\hline Did not answer & 11 & 26 & 7 & 25 & 4 & 27 \\
\hline \multicolumn{7}{|l|}{ Personal objects sharing } \\
\hline Do not practice & 23 & 53 & 17 & 61 & 6 & 40 \\
\hline Occasionally & 17 & 40 & 9 & 32 & 8 & 53 \\
\hline Frequently & 2 & 5 & 1 & 4 & 1 & 7 \\
\hline Did not answer & 1 & 2 & 1 & 4 & 0 & 0 \\
\hline
\end{tabular}

* Mann Whitney U $=1.9819 \mathrm{p}=0.0237$ [42]; http://department.obg.cuhk.edu.hk/researchsupport/MannWhitney.ASP).

The majority (53\%) of the women stated not to share spoons, toothbrush or candies (Table 2). But an important fraction $(40 \%)$ recognized to share those objects occasionally (Table 2).

\section{Discussion}

The prevalence rate of HPV in normal oral mucosa has been reported to vary greatly because of differences in types of samples, collection, detection methods, level of sensitivity, PCR primers used, and PCR inhibitors $[10,15,22-32]$. A previous study showed a high prevalence of oral HPV infection (81\%) among healthy people in Japan [20].

In this study, we performed the HPV detection by PCR using the MY09/MY11 primer pair; which, it is widely used on epidemiological studies and showed to be equally sensitive than confirmatory nested PCR with GP5+/GP6+ primers, with a correlation of 94\% [33-35]. Generic HPV in our sampled population had a frequency of $100 \%$.
These women that attend to the "Clinica de Displasias de Ciudad Juárez" can be considered as high risk population since they came to this clinic attending some cervical abnormality. It is notably interesting that all these women were positive and taking into account that they had some cervical problem; this number became comparable to the $81 \%$ found in oral cavity of healthy Japanese and the 90\% buccal HPV among positive genital HPV in Brazilian women $[7,20]$. Buccal presence of HPV16 in our study was $35 \%$ (Table 2). However, we have observed differences by the anatomic region of the oral cavity sampled that was $23 \%$ for buccal mucosa to $16 \%$ on P/G. To sum up, this HPV point prevalence was higher than those of other normal oral HPV studies as well as in high risk population $[20,26,30]$. The reasons of such a high HPV prevalence in the normal oral cavity in women of the City of Juarez are not yet explored. Further studies are needed to clarify this as well as the differences in HPV infection at each normal oral site and the use of 
condoms along with preventive vaccination as a strategy to prevent infections of the oral mucosa.

We evaluated HPVs only in buccal samples. Although in cancers of the upper aerodigestive tract HPV has been detected predominantly in the oropharynx and tonsil $[29,35]$. A risk factor for the occurrence of HPVinfected oral and for presence of HPV in the normal cervix is an increase in the number of sexual partners $[10,20,28]$, but in our study the number of sex partners did not seem to increase the risk of HPV-16 oral infection. Oral sex practices may affect oral and cervical sites similarly. Local factors that have been found to influence the persistence of HPV at the cervix may affect the natural history of oral HPV infections. These factors include coinfection by Chlamydia trachomatis $[30,31]$ or herpes simplex virus [32], smoking [36], age [37], HPV type [38], and the use of hormones and contraceptives $[23,36,39]$. However, all these reports did not implement any questionnaire to identify any factors behind the transmission of HPVs. We have collected information about sexual behavior of the patients, to examine the relationship between cunnilingus and incidence of mouth HPV infection.

In our study HPV16 in mouth was significantly associated with genital CIN progression (Mann Whitney U test, $\mathrm{p}=0.023)$, suggesting that women with HPV16 persistent infections and progression to advanced genital lesions have higher risk of HPV16 detection in the oral mucosa. We found HPV16 infection in a media of 37 years. As this type of HPV is related to cancer; it is also considered as high-risk mucosal type virus [40] and this phenomena should be known by the dentists and pathologists.

The role of men as possible vectors of HPV has been discussed previously [41]. Our results suggest that transmission of HPV occurs not only via sexual contact but also through oral contact. The fact that women that stated not to receive cunnilingus were HPV16 free; this probably reflects that their partner is not translocating the virus from the women genitals to the mouth but probably the autoinoculation is more frequent that we think.

In a cross-sectional study of Fahkyr [23], oral HPV infection was found to be less prevalent than cervical HPV infection in both HIV-positive and -negative women. Oral HPV infections were detected in approximately $25 \%$ of HIV-positive women and $9 \%$ of HIVnegative women. Our results showed a much higher prevalence in oral cavity of women with or without cervical lesions then the study of Fahkyr [23]. These data suggest that the oral cavity may be a reservoir of HPV infection with a sufficiently high prevalence to affect the dynamics of HPV transmission between the populations. Several aspects for the relationship among cervical- and oral-HPV remain poorly described. A prospective study to clarify the interrelationship between HPV infections at both sites and to understand possible differences in incidence and factors affecting clearance or persistence in the oral cavity and the cervix is warranted. These include differences by anatomic site in HPV prevalence and HPV type distribution. Also unknown are the prevalence of single and multiple oral or cervical infections and whether multiple infections are type concordant.

Our data hint, it is that oral cavity should be considered as a potential reservoir for HPV and may not be entirely independent of the cervical reservoir as well as the partner genitalia. In this study we did not sample the partner's genitalia but we assume that both genitalia are infected since these are considered as sexually transmissible infections. Thus the presence of the virus in the oral cavity should be explained not only by oral contact with genitalia but also by autoinoculation. We are aware about the different prevalence data in oral HPV DNA detection ought to different populations and methodologies. Consequently comparative studies will be required in parallel studies of the relationship between incident squamous epithelial lesions and persistence oral HPV. This will help to understand the involvement of HPV in the development of oral cancer as well as the role of oral cavity in the cervical infection.

\section{Conclusions}

In conclusion, this study suggests that women with genital HPV infection have also some kind of HPV infecting their oral cavity and HPV16 detection in the mouth is associated to HPV16 persistence in the genital tract and CIN progression.

\section{Methods}

\section{Patients and sampling}

This study was performed on summer 2008. All women had a previous CIN diagnosis between six months previous to the study. The Inclusion criteria were any women that attend to "Clínica de Displasias" for any cervical associated problem, no matter their origin or place of living (Mexico or USA), sign an informed consent and fill a questionnaire about their sex habits. The exclusion criteria were: smoking and alcoholism habits. All women studied were above eighteen years old. The full protocol was approved by the Ethics Committee of the Universidad Autonoma de Ciudad Juarez and the Clinica de Displasias. Women were asked to autosampling with a cotton swab the two cheeks and with other cotton swab the palate/gum $(\mathrm{P} / \mathrm{G})$. In both cases tissues were rubbed for a minute. Cotton swabs were immersed into $15 \mathrm{~mL}$ tube containing $1 \mathrm{~mL}$ of transporting media (10 mM Trizma, pH 8.8; 1 mM EDTA; 0.01\% Sodium azide; $50 \mu \mathrm{g} / \mathrm{mL}$ Ampicillin; $1 \mu \mathrm{g} / \mathrm{mL}$ Proteinase $\mathrm{K})$ and stored at $-20^{\circ} \mathrm{C}$ in between $24 \mathrm{~h}$ after collection. 


\section{DNA extraction and PCR for HPV}

Samples were unfreeze, centrifuged at 3,500 rpm in a clinical centrifuge, cotton swab removed and the transporting media was transferred to a $2 \mathrm{~mL}$ microtube that was centrifuged $5 \mathrm{~min}$ at $3,500 \mathrm{rpm}$ at $4^{\circ} \mathrm{C}$. $300 \mu \mathrm{L}$ of clear supernatant were taken into a new tube and $25 \mu \mathrm{L}$ of $5 \mathrm{M}$ sodium acetate and $1 \mathrm{~mL}$ of isopropanol were added consecutively and centrifuged at $14,000 \mathrm{rpm}$ at $4^{\circ}$ $\mathrm{C}$ for $5 \mathrm{~min}$. Pellet were washed with $1 \mathrm{~mL}$ of $70 \%$ ethanol and dried overnight at room temperature. Pellet was dissolved with $100 \mu \mathrm{L}$ rehydration solution (Promega A7963) and incubated at $65^{\circ} \mathrm{C}$ for $20 \mathrm{~min}$.

PCRs for generic HPVs were assembled with $5 \mu \mathrm{L}$ DNA, $12.5 \mu \mathrm{L} 2 \mathrm{X}$ GoTaq Green Master Mix (Promega). $5 \mu \mathrm{L}$ MY11/MY09 primer mix at $2.5 \mu \mathrm{M}$ each, and $2.5 \mu \mathrm{L}$ water. PCR conditions were 40 cycles at $94^{\circ} \mathrm{C}$ for $60 \mathrm{~s}, 55^{\circ} \mathrm{C}$ for $60 \mathrm{~s}, 72^{\circ} \mathrm{C}$ for $60 \mathrm{~s}$, with an initial denaturation at $94^{\circ} \mathrm{C}$ for $5 \mathrm{~min}$ and a final extension of $72^{\circ} \mathrm{C}$ for 7 min [33]. PCR products were examined in $2 \%$ agarose gels using base pairs standard (Promega G7521). PC04 and $\mathrm{GH} 20$ primers for human betha-globin gene were used as internal controls. For HPV16 and HPV18 specific primers were used as described elsewhere [34,35].

\section{Statistical analysis}

Questionnaire answers, previous histopathological results and buccal HPVs results were analyzed with SPSS statistical software version 11 and Mann Whitney U Test [42].

\section{Acknowledgements \\ This study was supported with funds of UACJ, "Clínica de Displasias" and the United Sates-Mexico Minority Health Interdisciplinary Research Training Program, http://www.nimhd.nih.gov/our_programs/mhirt.asp. We acknowledge also to Vanessa Mendez Galindo and Ana Gabriela Padilla Galindo for the proofreading. Part of this work was possible with stipends for internships to students by the United Sates-Mexico Minority Health Interdisciplinary Research Training Program, http://www.nimhd.nih.gov/ our_programs/mhirt.asp. All authors acknowledge to UACJ and the Clínica de Displasias, Ciudad Juarez, Mexico.}

\section{Author details}

1 Instituto de Ciencias Biomédicas, Universidad Autónoma de Ciudad Juárez Ciudad Juárez, Chihuahua, México. ${ }^{2}$ Clínica de Displasias. Jurisdicción Sanitaria No. II. Servicios de Salud de CHIH. Paseo Triunfo de la Republica No. 3530, Ciudad Juárez, CHIH Ciudad Juárez, Chihuahua, México.

\begin{abstract}
Authors' contributions
LS carried out the molecular genetic studies, participated in the sampling, and questionnaire design, analysis and drafted the manuscript. CD carried out the selection of patients, sampling, questionnaire application, and analysis of data. AM conceived of the study, and participated in its design, statistical analysis, writing and coordination of the study. All authors read and approved the final manuscript.
\end{abstract}

\section{Competing interests}

There are no conflicts of interest by any of the authors involved neither in this study publication nor for the previous 2 years.

Received: 21 April 2010 Accepted: 4 December 2010

Published: 4 December 2010
References

1. Bernard HU: The clinical importance of the nomenclature, evolution and taxonomy of human papillomaviruses. J Clin Virol 2005, 32(Suppl 1):S1-6.

2. Doorbar J: The papillomavirus life cycle. J Clin Virol 2005, 32(Suppl 1) S7-15.

3. Walboomers JM, Jacobs MV, Manos MM, Bosch FX, Kummer JA, Shah KV, Snijders PJ, Peto J, Meijer CJ, Muñoz N: Human papillomavirus is a necessary cause of invasive cervical cancer worldwide. J Pathol 1999, 189:12-19.

4. Flores $Y$, Shah $K$, Lazcano E, Hernández M, Bishai D, Ferris DG, Lörincz A, Hernández P, Salmerón J, Morelos HPV Study Collaborators: Design and methods of the evaluation of an HPV-based cervical cancer screening strategy in Mexico: The Morelos HPV Study. Salud Publica Mex 2002, 44:335-344.

5. International Agency for Research on Cancer. [http://www-dep.iarc.fr/].

6. Ibieta BR, Lizano M, Fras-Mendivil M, Barrera JL, Carrillo A, Ma Ruz-Godoy L, Mohar A: Human papilloma virus in oral squamous cell carcinoma in a Mexican population. Oral Surg Oral Med Oral Pathol Oral Radiol Endod 2005, 99:311-315

7. Rivero ER, Nunes FD: "HPV in oral squamous cell carcinomas of a Brazilian population: amplification by PCR. Braz Oral Res 2006, 20:21-24.

8. Andersson-Ellström A, Dillner J, Hagmar B, Schiller J, Forssman L: No serological evidence for non-sexual spread of HPV16. Lancet 1994, 344:1435.

9. Schwartz SM, Daling JR, Doody DR, Wipf GC, Carter JJ, Madeleine MM Mao EJ, Fitzgibbons ED, Huang S, Beckmann AM, McDougall JK, Galloway DA: Oral cancer risk in relation to sexual history and evidence of human papillomavirus infection. J Natl Cancer Inst 1998, 90:1626-1636

10. Giraldo P, Goncalves AK, Pereira SA, Barros-Mazon S, Gondo ML, Witkin SS: Human papillomavirus in the oral mucosa of women with genital human papillomavirus lesions. Eur J Obstet Gynecol Reprod Biol 2006, 126:104-106.

11. Rylander E, Ruusuvaara L, Almströmer MW, Evander M, Wadell G: The absence of vaginal human papillomavirus 16 DNA in women who have not experienced sexual intercourse. Obstet Gynecol 1994, 83:735-737.

12. Coutlée F, Trottier AM, Ghattas G, Leduc R, Toma E, Sanche G, Rodrigues I, Turmel B, Allaire G, Ghadirian P: Risk factors for oral human papillomavirus in adults infected and not infected with human immunodeficiency virus. Sex Transm Dis 1997, 24:23-31.

13. Kreimer AR, Alberg AJ, Daniel R, Gravitt PE, Viscidi R, Garrett ES, Shah KV, Gillison ML: Oral human papillomavirus infection in adults is associated with sexual behavior and HIV serostatus. J Infect Dis 2004, 189:686-698.

14. Harputluoglu H, Dizdar O, Altundag K: Prophylactic human papilloma virus vaccines for cervical cancer may also prevent development of breast and oropharyngeal cancers in women. Med Hypotheses 2006, 67:431-432.

15. Sugiyama M, Bhawal UK, Dohmen T, Ono S, Miyauchi M, Ishikawa T: Detection of human papillomavirus-16 and HPV-18 DNA in normal, dysplastic, and malignant oral epithelium. Oral Surg Oral Med Oral Pathol Oral Radiol Endod 2003, 95:594-600.

16. Badaracco G, Venutti A, di Lonardo A, Scambia G, Mozetti S, Benedetti Panici P, Mancuso S, Marcante ML: Concurrent HPV infection in oral and genital mucosa. J Oral Pathol Med 1998, 27:130-134.

17. Kellokoski JK, Syrjanen SM, Chang F, Yliskoski M, Syrjanen KJ: Southern blot hybridization and PCR in detection of oral human papillomavirus (HPV) infections in women with genital HPV infections. J Oral Pathol Med 1992, 21:459-464.

18. Hansson BG, Rosenquist $K$, Antonsson A, Wennerberg J, Schildt EB, Bladström A, Andersson G: Strong association between infection with human papillomavirus and oral and oropharyngeal squamous cell carcinoma: A population-based case-control study in southern Sweden. Acta Otolaryngol 2005, 125:1337-1344

19. Kay P, Meehan K, Williamson AL: The use of nested polymerase chain reaction and restriction fragment length polymorphism for the detection and typing of mucosal human papillomaviruses in samples containing low copy numbers of viral DNA. J Virol Methods 2002, 105:159-170.

20. Kurose K, Terai M, Soedarsono N, Rabello D, Nakajima Y, Burk RD, Takagi M: Low prevalence of HPV infection and its natural history in normal oral mucosa among volunteers on Miyako Island, Japan. Oral Surg Oral Med Oral Pathol Oral Radiol Endod 2004, 98:91-96. 
21. Rice PS, Mant C, Cason J, Bible JM, Muir P, Kell B, Best JM: High prevalence of human papillomavirus type 16 infection among children. J Med Virol 2000, 61:70-75.

22. Cañadas MP, Bosch FX, Junquera ML, Ejarque M, Font R, Ordoñez E, de Sanjosé S: Concordance of prevalence of human papillomavirus DNA in anogenital and oral infections in a high-risk population. J Clin Microbiol 2004, 42:1330-1332.

23. Fakhry C, D'souza G, Sugar E, Weber K, Goshu E, Minkoff H, Wright R, Seaberg E, Gillison M: Relationship between Prevalent Oral and Cervical Human Papillomavirus Infections in Human Immunodeficiency VirusPositive and -Negative Women. J Clin Microbiol 2006, 44:4479-4485.

24. Giovannelli L, Campisi G, Lama A, Giambalvo O, Osborn J, Margiotta V, Ammatuna P: Human papillomavirus DNA in oral mucosal lesions. J Infect Dis 2002, 185:833-836.

25. Summersgill KF, Smith EM, Levy BT, Allen JM, Haugen TH, Turek LP: Human papillomavirus in the oral cavities of children and adolescents. Oral Surg Oral Med Oral Pathol Oral Radiol Endod 2001, 91:62-69.

26. Terai M, Hashimoto K, Yoda K, Sata T: High prevalence of human papillomaviruses in the normal oral cavity of adults. Oral Microbiol Immunol 1999, 14:201-205.

27. Lambropoulos AF, Dimitrakopoulos J, Frangoulides E, Katopodi R, Kotsis A Karakasis D: Incidence of human papillomavirus $6,11,16,18$ and 33 in normal oral mucosa of a Greek population. Eur J Oral Sci 1997, 105:294-297.

28. Woodman CB, Collins S, Winter H, Bailey A, Ellis J, Prior P, Yates M, Rollason TP, Young LS: Natural history of cervical human papillomavirus infection in young women: a longitudinal cohort study. Lancet 2001, 357:1831-1836.

29. Herrero R: Human papillomavirus and cancer of the upper aerodigestive tract. J Natl Cancer Inst Monogr 2003, 31:47-51.

30. Samoff E, Koumans EH, Markowitz LE, Sternberg M, Sawyer MK, Swan D, Papp JR, Black CM, Unger ER: Association of Chlamydia trachomatis with persistence of high-risk types of human papillomavirus in a cohort of female adolescents. Am J Epidemiol 2005, 162:668-675.

31. Silins I, Ryd W, Strand A, Wadell G, Törnberg S, Hansson BG, Wang X, Arnheim L, Dahl V, Bremell D, Persson K, Dillner J, Rylander E: Chlamydia trachomatis infection and persistence of human papillomavirus. Int $J$ Cancer 2005, 116:110-115.

32. Smith JS, Herrero R, Bosetti C, Muñoz N, Bosch FX, Eluf-Neto J, Castellsagué X, Meijer CJ, Van den Brule AJ, Franceschi S, Ashley R, International Agency for Research on Cancer (IARC) Multicentric Cervical Cancer Study Group: Herpes simplex virus-2 as a human papillomavirus cofactor in the etiology of invasive cervical cancer. J Natl Cancer Inst 2002, 94:1604-1613.

33. Zehbe I, Wilander E: Two consensus primer systems and nested polymerase chain reaction for human papillomavirus detection in cervical biopsies: A study of sensitivity. Hum Pathol 1996, 27:812-815.

34. Pao CC, Lin SS, Lin CY, Maa JS, Lai CH, Hsieh TT: Identification of human papillomavirus DNA sequences in peripheral blood mononuclear cells. Am J Clin Pathol 1991, 95:540-546.

35. Peñaloza-Plascencia M, Montoya-Fuentes $H$, Flores-Martínez SE, FierroVelasco FJ, Peñaloza-González JM, Sánchez-Corona J: Molecular identification of 7 human papillomavirus types in recurrent respiratory papillomatosis. Arch Otolaryngol Head Neck Surg 2000, 126:1119-1123.

36. Castellsague X, Muñoz N: Chapter 3. Cofactors in human papillomavirus carcinogenesis-role of parity, oral contraceptives, and tobacco smoking. J Natl Cancer Inst Monogr 2003, 31:20-28.

37. Castle PE, Schiffman M, Herrero R, Hildesheim A, Rodriguez AC, Bratti MC, Sherman ME, Wacholder S, Tarone R, Burk RD: A prospective study of age trends in cervical human papillomavirus acquisition and persistence in Guanacaste, Costa Rica. J Infect Dis 2005, 191:1808-1816.

38. Schiffman M, Herrero R, Desalle R, Hildesheim A, Wacholder S, Rodriquez AC, Bratti MC, Sherman ME, Morales J, Guillen D, Alfaro M, Hutchinson M, Wright TC, Solomon D, Chen Z, Schussler J, Castle PE, Burk RD: The carcinogenicity of human papillomavirus types reflects viral evolution. Virology 2005, 337:76-84.

39. Muñoz N, Franceschi S, Bosetti C, Moreno V, Herrero R, Smith JS, Shah KV, Meijer CJ, Bosch FX, International Agency for Research on Cancer. Multicentric Cervical Cancer Study Group: Role of parity and human papillomavirus in cervical cancer: the IARC multicentric case-control study. Lancet 2002, 359:1093-1101.
40. Chow LT, Broker TR, Steinberg BM: The natural history of human papillomavirus infections of the mucosal epithelia. APMIS 2010, 118:422-449.

41. Bosch FX, Castellsagué X, Muñoz N, de Sanjosé S, Ghaffari AM, González LC, Gili M, Izarzugaza I, Viladiu P, Navarro C, Vergara A, Ascunce N, Guerrero E, Shah KV: Male sexual behavior and human papillomavirus DNA: key risk factors for cervical cancer in Spain. J Natl Cancer Inst 1996, 88:1060-1067.

42. Siegal S, Castellan NJ Jr: Nonparametric statistics for the Behavioral Sciences. McGraw Hill Book Company New York; 2 1988, ISBN 0-07-0573573 0. (Mann Whitney Wilcoxon p128-137) (Robust Rank Order Test also called Mann Whitney U Test p. 137-144).

doi:10.1186/1750-9378-5-25

Cite this article as: Sánchez-Vargas et al:: Detection of Human Papilloma Virus (HPV) in oral mucosa of women with cervical lesions and their relation to oral sex practices. Infectious Agents and Cancer 2010 5:25.

\section{Submit your next manuscript to BioMed Central and take full advantage of:}

- Convenient online submission

- Thorough peer review

- No space constraints or color figure charges

- Immediate publication on acceptance

- Inclusion in PubMed, CAS, Scopus and Google Scholar

- Research which is freely available for redistribution

Submit your manuscript at www.biomedcentral.com/submit
Ciomed Central 